\title{
PENGARUH TERAPI MUSIK KLASIK (BEETHOVEN) TERHADAP PENURUNAN KECEMASAN PADA PASIEN YANG MENJALANI HEMODIALISA DENGAN GAGAL GINJAL KRONIK DI RSUD DR. M YUNUS BENGKULU
}

\section{THE EFFECT OF CLASSIC MUSIC THERAPY (BEETHOVEN) ON REDUCING ANXIETY IN HEMODIALISA PATIENTS IN DR. YUNUS BENGKULU HOSPITAL}

\author{
Oleh: \\ Liza Fitri Lina1, Meri Susanti², Fatsiwi Nunik ${ }^{3}{ }^{3}$, Haifa Wahyu ${ }^{4}$, dan Dodi Efrisnal5 \\ 1,3,4Dosen, Prodi keperawatan, Universtitas muhammadiyah Bengkulu \\ 2,5Alumni, Prodi keperawatan dan Prodi Profesi Ners, Universtitas muhammadiyah Bengkulu \\ Lizafitrilina@umb.ac.id
}

\begin{abstract}
The chronic kidney disease (CKD) is a world health problem with a high burden of health costs. The actions taken to treat CKD are hemodialysis $(\mathrm{Hd})$. The process of hemodialysis often causes anxiety in patients. The purpose of this study was to determine the effect of beethoven on classical anxiety levels in Hemodialysis patients at Dr. M Yunus Bengkulu. This type of research is quantitative research that uses the research design of one group pre-test-posttest design. The population in this study were all hemodialysis patients at Dr. M Yunus Bengkulu. Samples taken were 15 hemodialysis patients. The results of the study were obtained; before being given classical music therapy (Beethoven), out of 15 hemodialysis patients, 12 patients (80\%) experienced severe anxiety while 3 other patients $(20 \%)$ experienced moderate anxiety. After being given classical music therapy (Beethoven), out of 15 hemodialysis patients, there were 2 patients $(13.33 \%)$ experiencing mild anxiety, 11 patients (73.34\%) experiencing moderate anxiety, and 2 other patients $(13.33 \%)$ experiencing severe anxiety. Based on the results of the dependent $t$ test, obtained $t=10,960$ and $p$ value $=0,000$. Because $p$-value $=0,000<0,05$. Concluded that there is a significant effect of therapy in playing classical music (Beethoven) on the level of anxiety in hemodialysis patients in Dr. RSUD. M Yunus Bengkulu.
\end{abstract}

Keywords : anxiety, hemodialysis, Beethoven's classical music

\begin{abstract}
ABSTRAK
Penyakit ginjal kronik (GGK) merupakan masalah kesehatan dunia dengan beban biaya kesehatan yang tinggi. Tindakan yang dilakukan untuk penanganan GGK adalah hemodialisa $(\mathrm{Hd})$. Proses hemodialisa seringkali menimbulkan kecemasan pada pasien. Tujuan penelitian ini adalah untuk mengetahui pengaruh terapi musik klasik (beethoven) terhadap tingkat kecemasan pada pasien Hemodialisa di RSUD Dr. M Yunus Bengkulu. Jenis penelitian ini adalah penelitian kuantitatif yang menggunakan desain penelitian one group pra-test-posttest design. Populasi dalam penelitian ini adalah seluruh pasien hemodialisa di RSUD Dr. M Yunus Bengkulu. Sampel yang diambil sebanyak 15 orang pasien hemodialisa. Hasil penelitian diperoleh bahwa sebelum diberikan terapi musik klasik (Beethoven), dari 15 pasien hemodialisa, terdapat 12 pasien (80\%) mengalami kecemasan berat sedangkan 3 pasien lainnya (20\%) mengalami kecemasan sedang. Setelah diberikan terapi musik klasik (Beethoven), dari 15 pasien hemodialisa, terdapat 2 pasien $(13,33 \%)$ mengalami kecemasan ringan, 11 pasien $(73,34 \%)$ mengalami kecemasan sedang, dan 2 pasien lainnya $(13,33 \%)$ mengalami kecemasan berat. Berdasarkan hasil uji t dependent, diperoleh $t=10,960$ dan $p$-value $=$ 0,000 . Karena $p$-value $=0,000<0,05$. Disimpulkan bahwa terdapat pengaruh signifikan terapi bermain musik klasik (Beethoven) terhadap tingkat kecemasan pada pasien hemodialisa di RSUD Dr. M Yunus Bengkulu.
\end{abstract}

Kata Kunci : kecemasan, hemodialisa, musik klasik beethoven 


\section{PENDAHULUAN}

Penyakit ginjal kronik merupakan masalah kesehatan dunia dengan beban biaya kesehatan yang tinggi. Gagal Ginjal Kronik (GGK) merupakan ketidakmampuan tubuh gagal dalam mempertahankan metabolisme dan kesimbangan cairan (Siti Purwati, 2018) Data Global Burden of Disease tahun 2010 menunjukkan bahwa penyakit ginjal kronik merupakan penyebab kematian urutan ke 18 pada tahun 2010. Angka kejadian gagal ginjal di dunia secara global lebih dari 500 juta orang dan yang harus menjalani Hemodialisis sekitar 1,5 juta orang (Yesi H \& Bayhakki, 2017).

Lebih dari 2 juta penduduk di dunia mendapatkan perawatan dengan dialisis atau transplantasi ginjal dan hanya sekitar 10\% yang benar-benar mengalami perawatan tersebut (Kemenkes RI, 2017). Kemudian prevalensi gagal ginjal kronik di Asia terus mengalami peningkatan, misalnya, di Taiwan (2.990/1.000.000 penduduk) dan Jepang (2.590/ 1.000.000 penduduk) (Cipta, 2016).

Data Riset Kesehatan Dasar (Riskesdas) tahun 2013, menunjukkan bahwa prevalensi penduduk Indonesia yang menderita gagal ginjal sebesar $0,2 \%$ atau 2 per 1000 penduduk dan prevalensi gagal ginjal kronik sebesar $0,6 \%$ atau 6 per 1000 penduduk dan pada tahun 2016 sebesar $98 \%$ penderita gagal ginjal menjalani terapi hemodialisis dan $2 \%$ menjalani terapi peritoneal dialisis (PD) (Kemenkes RI, 2017).

Gagal ginjal kronis merupakan penyakit ginjal tahap akhir dimana pasien akan mengalami ketidakmampuan tubuh untuk mempertahankan metabolisme dan keseimbangan cairan dan elektrolit (Suharyanto dan Madjid, 2009). Gejala bisa muncul dari penyakit diabetes mellitus (Simulati, 2015). Gagal ginjal biasanya berakibat akhir dari kehilangan fungsi ginjal lanjut secara bertahap, dari stadium I hingga stadium III. Pada stadium III atau stadium akhir, penderita mulai merasakan gejala yang cukup parah karena ginjal sudah tidak sanggup lagi mempertahankan homeostatis cairan dan elektrolit dalam tubuh. Pengobatan gagal ginjal stadium akhir ini dapat berupa transplantasi ginjal atau cuci darah (Hemodialisis) (Ariani, 2016).

Pasien yang menjalani hemodialisa (HD) mengalami berbagai masalah yang timbul akibat tidak berfungsinya ginjal. Hal tersebut muncul setiap waktu sampai akhir kehidupan. Hal ini menjadi stresor fisik yang berpengaruh pada berbagai dimensi kehidupan pasien yang meliputi bio, psiko, sosio, spiritual. Kelemahan fisik yang dirasakan seperti mual, muntah, nyeri, lemah otot, oedema adalah sebagian dari manifestasi klinik dari pasien yang menjalani hemodialisa. Ketidakberdayaan serta kurangnya penerimaan diri pasien menjadi faktor psikologis yang mampu mengarahkan pasien pada tingkat stres, kecemasan bahkan depresi (Ratnawati, 2011).

Kecemasan bagian dari kehidupan sehari-hari dan hampir semua individu pernah mengalami kecemasan dan pada tahap tertentu akan berakibat buruk bagi kesehatan. Kecemasan merupakan pengalaman subjektif yang tidak menyenangkan mengenai kekhawatiran atau ketegangan berupa perasaan cemas, tegang dan emosi yang dialami oleh seseorang (Ghufron dan Rini, 2011).

Masing-masing pasien yang menjalani hemodialisis biasanya memiliki respon yang berbeda terhadap hemodialisis yang sedang dijalaninya, contohnya pasien akan merasa cemas yang disebabkan oleh krisis situasional, ancaman kematian, dan tidak mengetahui hasil akhir dari terapi yang dilakukan tersebut. Pada pasien gagal ginjal yang sudah sering melakukan hemodialisis tingkat kecemasan lebih ringan, berbeda dengan pasien gagal ginjal yang baru pertama kali melakukan hemodialisis akan mengalami kecemasan yang lebih tinggi (Tangian, Kandou dan Munayang, 2015).

Rustam (2012) menyatakan bahwa kecemasan sering terjadi pada klien gagal ginjal kronik ketika memulai hemodialisa, perilaku koping seperti mengingkari, marah, pasif atau agresif umum dijumpai pada pasien. Sering kali dijumpai upaya koping tidak efektif pada pasien yang menjalani hemodialisis dan hal tersebut dapat membuat keadaan tegang 
meningkat pada pasien hemodialisis sehingga terjadi peningkatan kebutuhan energi lalu sumber penyakit nampak lebih besar

Di Kota Bengkulu, pelayanan pasien hemodialisa terpusat di tiga rumah sakit yaitu Rumah Sakit Bhayangkara, Rumah Sakit Raflesia, dan RSUD Dr. M Yunus Bengkulu. Pelayanan hemodialisa di RS Raflesia cukup banyak dikunjungi oleh pasien, namun pelayanan tersebut masih terkendala dengan jumlah fasilitas yang tersedia. Demikian juga dengan pelayanan pasien hemodialisa di RS Bhayangkara dalam beberapa tahun terakhir terkendala dengan pengembangan fasilitas yang dilakukan di rumah sakit tersebut.

Pelayanan pasien hemodialisa selama ini terpusat di RSUD Dr. M Yunus Bengkulu. Hal ini dikarenakan RSUD Dr. M Yunus merupakan rumah sakit pusat rujukan sehingga jumlah kunjungan pasien hemodialisa yang berkunjung cukup banyak. Data RSUD Dr. M Yunus Bengkulu menyebutkan bahwa pada tahun 2015 terdapat 383 pasien gagal ginjal kronik yang menjalani rawat inap di RSUD Dr. M Yunus Bengkulu, dimana 52 pasien diantaranya berakhir dengan kematian. Pada tahun 2016, terdapat 363 pasien gagal ginjal kronik yang menjalani rawat inap di RSUD Dr. M Yunus Bengkulu dimana 46 pasien diantaranya meninggal dunia. Dan pada tahun 2017, terdapat 333 pasien gagal ginjal kronik yang menjalani rawat inap dan 36 pasien diantaranya meninggal dunia.

Berdasarkan survei awal tanggal 25 Oktober 2018 di ruangan hemodialisis RSUD Dr. M Yunus Bengkulu, dari 5 orang pasien yang di wawancarai ditemukan 3 orang mengatakan bahwa mereka cemas dengan terapi hemodialisis yang sedang dijalaninya, cemas terhadap mesin, selang-selang yang dialiri darah, dan cemas saat ditusuk jarum.

Berdasarkan latar belakang di atas, peneliti tertarik untuk meneliti pengaruh terapi musik klasik terhadap tingkat kecemasan pasien hemodialisa dengan gagal ginjal kronik di RSUD Dr. M Yunus Bengkulu.

\section{METODE PENELITIAN}

Jenis penelitian ini merupakan penelitian kuantitatif yang menggunakan desain penelitian one group pra-test-posttest design, yang merupakan penelitian eksperimen semu (Sugiyono, 2018). di mana penelitian tidak mempunyai kelompok pembanding (kontrol), tetapi peneliti membandingkan tingkat kecemasan pasien hemodialisa dengan gagal ginjal kronik di RSUD Dr. M. Yunus Bengkulu sebelum dan setelah pemberian terapi musik klasik (Beethoven). Penelitian dilakukan pada tanggal 06 Desember 2018 - 06 Januari 2019 di ruang Hemodialisa RSUD Dr. M Yunus Bengkulu. Populasi dalam penelitian ini adalah seluruh pasien hemodialisa yang mengalami gagal ginjal kronik di RSUD Dr. M Yunus Bengkulu. Pengambilan sampel dalam penelitian ini menggunakan teknik purposive sampling sebanyak 15 responden, yang memenuhi kriteria inklusi:

Pasien gagal ginjal kronik yang mengalami kecemasan ringan, sedang, dan berat, Bersedia menjadi responden, Punya rasa cemas, Bisa diajak berkomunikasi dan kerjasama, Tidak mengalami gangguan pendengaran.

Kriteria ekslusi dalam penelitian ini adalah:

Mundur menjadi responden, Mengalami gangguan kesadaran.

Pengumpulan data primer pada penelitian ini diperoleh dengan cara melakukan pengukuran kecemasan pada pasien hemodialisa saat sebelum dan setelah pemberian terapi musik klasik (Beethoven). Pengumpulan data sekunder diperoleh dari RSUD Dr. M Yunus Bengkulu berupa rekam medik pasien hemodilisa yang menjalani cuci darah di ruang hemodialis di RSUD Dr. M Yunus Bengkulu selama waktu penelitian.

Penelitian dilakukan selama 4 minggu dengan jumlah pertemuan sebanyak 1 kali pada setiap responden. Dalam 1 kali pertemuan dilakukan pengukuran tingkat kecemasan pasien hemodialisa sebelum diberikan terapi musik klasik (beethoven) dan setelah diberikan terapi musik klasik 
(beethoven). Hasil pengukuran kecemasan sebelum dan setelah perlakuan akan diuji, apakah terdapat perbedaan kecemasan pada sampel penelitian.

Data dianalisis menggunakan analisis univariat, uji normalitas data dan analisis bivariat.

HASIL

\section{Analisis Univariat}

Tabel 1. Distribusi Frekuensi Tingkat Kecemasan Pada Pasien Hemodialisa Dengan Gagal Ginjal Kronik Sebelum Diberikan Terapi Musik Klasik (Beethoven) Di RSUD Dr. M Yunus Bengkulu Tahun 2018

\begin{tabular}{ccc}
\hline $\begin{array}{c}\text { Tingkat } \\
\text { Kecemasan }\end{array}$ & Frekuensi & $\begin{array}{c}\text { Persentase } \\
(\mathbf{\%})\end{array}$ \\
\hline Ringan & 0 & 0,0 \\
\hline Sedang & 3 & 20,0 \\
\hline Berat & 12 & 80,0 \\
\hline Total & 15 & 100,0 \\
\hline
\end{tabular}

Berdasarkan Tabel 1 di atas dapat dilihat bahwa pada 15 pasien hemodialisa dengan gagal ginjal kronik saat sebelum diberikan terapi musik klasik (Beethoven), diperoleh hasil bahwa yang mengalami kecemasan berat sebesar $12 \quad(80 \%)$ sedangkan yang mengalami kecemasan sedang sebesar $3(20 \%)$.

Tabel 2. Distribusi Frekuensi Tingkat Kecemasan Pada Pasien Hemodialisa Dengan Gagal Ginjal Kronik Setelah Diberikan Terapi Musik Klasik (Beethoven) di RSUD Dr. M Yunus Bengkulu Tahun 2018

\begin{tabular}{ccc}
\hline $\begin{array}{c}\text { Tingkat } \\
\text { Kecemasan }\end{array}$ & Frekuensi & $\begin{array}{c}\text { Persentase } \\
\mathbf{( \% )}\end{array}$ \\
\hline Ringan & 2 & 13,33 \\
\hline Sedang & 11 & 73,34 \\
\hline Berat & 2 & 13,33 \\
\hline Total & 15 & 100,0 \\
\hline
\end{tabular}

Berdasarkan Tabel 2 di atas dapat dilihat bahwa pada 15 pasien hemodialisa dengan gagal ginjal kronik saat setelah diberikan terapi musik klasik (Beethoven) diperoleh hasil bahwa yang mengalami kecemasan sedang sebesar 11 (73,34\%), yang mengalami kecemasan ringan sebesar 2 $(13,33 \%)$ dan yang mengalami kecemasan berat $2(13,33 \%)$.

\section{Hasil Uji Normalitas Data}

Tabel 3. Hasil Uji Normalitas Data Kecemasan Pasien Hemodialisa Pada

Saat Sebelum dan Setelah Terapi Musik Klasik (Beethoven) di RSUD Dr. M Yunus Bengkulu Tahun 2018

\begin{tabular}{cccc}
\hline Kelompok & \multicolumn{3}{c}{ Shapiro-Wilk } \\
\cline { 2 - 4 } Sampel & Statistik & df & Sig \\
\hline $\begin{array}{c}\text { Kecemasan } \\
\text { sebelum terapi } \\
\text { musik klasik }\end{array}$ & .984 & 15 & .990 \\
\hline $\begin{array}{c}\text { Kecemasan } \\
\text { setelah terapi } \\
\text { musik klasik }\end{array}$ & .947 & 15 & .474 \\
\hline
\end{tabular}

Pada Tabel 3 dapat dilihat bahwa untuk data kecemasan pasien hemodialisa sebelum diberikan terapi musik klasik (Beethoven) diperoleh nilai statistik Saphiro-Wilk sebesar 0,984 dan $p$-value $=0,990$. Karena nilai $p$ value $=0,990>0,05$ maka dapat disimpulkan bahwa data tersebut berdistribusi normal. Kemudian pada data kecemasan pasien hemodialisa setelah diberikan terapi musik klasik (Beethoven) diperoleh nilai statistik Saphiro-Wilk sebesar 0,947 dan $p$-value = 0,474 . Karena $p$-value $=0,474>0,05$ maka dapat disimpulkan bahwa data kecemasan pasien hemodialisa setelah diberikan terapi musik klasik (Beethoven) berdistribusi normal.

Berdasarkan uji normalitas data ini dapat disimpulkan bahwa data kecemasan baik sebelum maupun setelah terapi musik klasik (Beethoven) berdistribusi normal sehingga uji pengaruh terapi musik klasik (Beethoven) terhadap kecemasan pasien hemodialisa dilakukan dengan menggunakan uji t dependen.

\section{Hasil Analisis Bivariat}

Tabel 4. Pengaruh Terapi Musik Klasik (Beethoven) Terhadap Tingkat

14 Vol. 15, No. 1, April $2020: 1$ - 73 | 
Kecemasan Pasien Hemodialisa di RSUD Dr. M Yunus Bengkulu Tahun 2018

\begin{tabular}{ccccccc}
\hline Kelompok & N & Mean & $\begin{array}{c}\text { Std. } \\
\text { Deviasi }\end{array}$ & T & Df $\begin{array}{c}\text { Sig. (2- } \\
\text { tailed) }\end{array}$ \\
\hline Sebelum & 15 & 32,47 & 6,621 & 10,960 & 14 & .000 \\
\hline Setelah & 15 & 20,53 & 4,704 & & \\
\hline
\end{tabular}

Pada Tabel 4. dapat dilihat bahwa pada saat sebelum diberikan terapi musik klasik (Beethoven), rata-rata skor kecemasan pada pasien hemodialiasa adalah 32,47 dan standar deviasi sebesar 6,621, sedangkan pada saat setelah diberikan terapi musik klasik (Beethoven) diperoleh rata-rata skor kecemasan sebesar 20,53 dan standar deviasi sebesar 4,704. Berdasarkan hasil uji $t$ dependent, diperoleh $t=10,960$ dan $p$-value $=$ 0,000 . Karena $p$-value $=0,000<0,05$ maka dapat disimpulkan bahwa terdapat pengaruh yang signifikan pemberian terapi musik klasik (Beethoven) terhadap tingkat kecemasan pada pasien hemodialisa di RSUD Dr. M Yunus Bengkulu.

\section{PEMBAHASAN}

Distribusi Frekuensi Tingkat Kecemasan Pasien Hemodialisa Dengan Gagal Ginjal Kronik Sebelum Diberikan Terapi Musik Klasik (Beethoven)

Tingkat kecemasan pasien hemodialisa diukur menggunakan kuesioner Hamilton Anxiety Rating Scale (HARS) yang terdiri dari 14 pertanyaan. Berdasarkan hasil penelitian didapatkan bahwa dari 15 pasien hemodialisa dengan gagal ginjal kronik sebelum diberikan terapi musik klasik (Beethoven) yang mengalami kecemasan berat sebesar 12 $(80 \%)$ dan pasien yang mengalami kecemasan sedang sebesar $3(20 \%)$.

Berdasarkan hasil penelitian dapat diuraikan bahwa pasien gagal ginjal kronik yang menjalani hemodialisa saat sebelum diberikan terapi musik klasik (Beethoven), yang mengalami kecemasan berat yaitu sebesar $12(80 \%)$ pasien terkait dengan pertanyaan nomor 3 dengan skor total 41 yaitu gejala ketakutan pada gelap, ditinggal sendiri, pada orang asing, pada keramaian lalu lintas dan pada kerumunan orang banyak. Kemudian pasien juga mengeluhkan keadaan terkait dengan pertanyaan nomor 7 dengan skor total 40 yaitu gejala somatik berupa nyeri otot, kaku, kedutan otot, gigi gemerutuk, dan suara tidak stabil. Sedangkan pada pasien gagal ginjal kronik yang mengalami kecemasan sedang yaitu sebesar $3(20 \%)$ pasien, lebih banyak mengalami keadaan kecemasan yang terkait dengan pertanyaan nomor 1,2 , dan 3 yaitu perasaan cemas, ketegangan dan ketakutan pada taraf sedang.

\section{Distribusi Frekuensi Tingkat Kecemasan Pasien Hemodialisa Dengan Gagal Ginjal Kronik Setelah Diberikan Terapi Musik Klasik (Beethoven)}

Berdasarkan hasil penelitian diperoleh bahwa dari 15 pasien hemodialisa dengan gagal ginjal kronik saat setelah diberikan terapi musik klasik (Beethoven), didapatkan bahwa yang mengami kecemasan sedang 11 $(73,34 \%)$, mengalami kecemasan ringan 2 $(13,33 \%)$ dan yang mengalami kecemasan berat $2(13,33 \%)$. Hasil ini menunjukkan bahwa setelah pasien hemodialisa mendapatkan terapi musik klasik (Beethoven) terjadi perubahan pada tingkat kecemasan pasien hemodialisa.

Berdasarkan hasil penelitian dapat diuraikan bahwa pasien gagal ginjal kronik yang menjalani hemodialisa saat setelah diberikan terapi musik klasik (Beethoven), yang masih mengalami kecemasan berat sebesar $2(13,33 \%)$ terkait dengan pertanyaan nomor $5,10,12$, dan 13 yaitu merasa mengalami gangguan kecerdasan, gejala pernafasan, gejala urogenitalia, dan gejala vegetative pada taraf berat. Kemudian yang mengalami kecemasan sedang sebesar 11 $(73,34 \%)$ yang mengalami kecemasan sedang dapat diuraikan bahwa terkait dengan pertanyaan nomor $1,2,4,5,13$, dan 14 yaitu sebagian dari perasaan cemas, ketegangan, gangguan tidur, gejala vegetatif, dan perasaan seperti tidak tenang, muka merah, dan gelisah masing-masing pada taraf sedang. Dan pada pasien dengan kecemasan ringan sebesar 2 
$(13,33 \%)$ dapat diuraikan bahwa hampir seluruh dari gejala dirasakan oleh pasien, namun hanya satu diantaranya dari gejalagejala yang ada pada masing-masing pertanyaan.

Selama penelitian, pasien terlihat menikmati terapi musik yang diberikan Menurut peneliti, irama musik klasik (Beethoven) yang didengarkan kepada pasien hemodialisa dapat menstimulus relaksasi pada pasien sehingga terjadi penurunan kecemasan pada pasien. Oleh karena itu, terapi musik klasik (Beethoven) dapat menjadi salah satu cara untuk mengurangi kecemasan pada pasien.

\section{Pengaruh Terapi Musik Klasik (Beethoven) Terhadap Tingkat Kecemasan Pasien Hemodialisa Dengan Gagal Ginjal Kronik di RSUD Dr. M Yunus Bengkulu}

Berdasarkan distribusi frekuensi tingkat kecemasan pasien hemodialisa di RSUD Dr. M Yunus saat sebelum dan setelah pemberian terapi musik klasik terlihat perubahan frekuensi dan persentase tingkat kecemasan pasien. Sebelum diberikan terapi musik klasik (Beethoven), dari 15 responden didapatkan bahwa pasien yang mengalami kecemasan berat sebesar 12 (80\%) sedangkan setelah diberikan terapi musik klasik (Beethoven) didapatkan bahwa pasien hemodialisa yang mengalami kecemasan berat $2(13,33 \%)$ kemudian saat sebelum diberikan terapi musik klasik (Beethoven) didapatkan bahwa pasien hemodialisa yang mengalami kecemasan sedang sebesar $3(20 \%)$ namun setelah diberikan terapi musik klasik (Beethoven) pasien hemodialisa yang mengalami kecemasan sedang sebesar $13(73,34 \%)$. Hal ini berarti pasien yang awalnya mengalami kecemasan berat sebelum diterapi, tingkat kecemasannya mengalami penurunan. Bahkan setelah diberikan terapi musik klasik (Beethoven) pasien hemodialisa hanya mengalami kecemasan ringan sebesar 2 $(13,33 \%)$.

Berdasarkan skor rata-rata, diperoleh hasil bahwa rata-rata skor kecemasan pada pasien hemodialisa adalah 32,47 dan standar deviasi sebesar 6,621, sedangkan pada saat setelah diberikan terapi musik klasik (Beethoven) diperoleh rata-rata skor kecemasan sebesar 20,53 dan standar deviasi sebesar 4,704. Hasil ini menunjukkan bahwa terjadi penurunan rata-rata skor HARS pada pasien hemodialisa saat sebelum dan setelah diberikan terapi musik klasik (Beethoven) dan deviasi antar skor juga mengalami penurunan.

Berdasarkan hasil uji $t$ dependent, diperoleh $\mathrm{t}=10,960$ dan $\mathrm{p}$-value $=0,000$. Karena $p$-value $=0,000<0,05$ maka dapat disimpulkan bahwa terdapat pengaruh signifikan terapi musik klasik (Beethoven) terhadap tingkat kecemasan pada pasien hemodialisa di RSUD Dr. M Yunus Bengkulu. Pengaruh tersebut adalah pasien yang mendapatkan terapi musik klasik (Beethoven) mengalami penurunan tingkat kecemasan setelah diberikan terapi.

Menurut peneliti, pemberian terapi musik klasik (Beethoven) membuat pasien hemodialisa merasa relaks dan nyaman sehingga dapat menurunkan kecemasan yang dialaminya. Menurut Turana (2011), alunan musik dapat menstimulasi tubuh untuk memproduksi molekul yang disebut nitrik oxide (NO). Molekul ini bekerja pada tonus pembuluh darah sehingga dapat mengurangi kecemasan dan menumbuhkan perasaan relaks pada pasien.. Dengan begitu, maka akan sangat bermanfaat jika musik klasik (beethoven) dapat digunakan untuk penurunan kecemasan pada pasien hemodialisa.

Hasil penelitian ini sesuai dengan penelitian Prihananda, Maliya, dan Kartinah (2016) yang menyimpulkan bahwa terdapat pengaruh signifikan terapi musik klasik terhadap kecemasan pada pasien hemodialisa, dimana terjadi penurunan ratarata skala kecemasan pada kelompok musik klasik dari angka 29,67 menjadi 17,33. Pasien hemodialisa dengan program terapi dua kali seminggu lebih mudah mengatasi kecemasannya dibanding dengan pasien yang baru menjalani program terapi hemodialisa termasuk yang satu kali seminggu.

Dalam penelitian ini musik klasik yang digunakan untuk terapi adalah musik klasik karya Beethoven yang berdurasi kurang lebih 5 menit. Menurut Potter \& Perry (2010), terapi 
musik klasik memperpanjang serat otot, mengurangi impuls neural ke otak, dan selanjutnya mengurangi aktivitas otak juga sistem tubuh lainnya. Sehingga respon tubuh akan terjadi penurunan denyut jantung dan frekuensi pernapasan, tekanan darah, dan konsumsi oksigen serta aktivitas otak alpha dan suhu kulit bagian perifer. Mahatadinar dan Nisa (2017) mengatakan bahwa musik klasik adalah esensi keteraturan dan membaca pada semua hal yang baik, adil dan indah. Berdasarkan pengertian musik secara umum, musik klasik diartikan sebagai suatu cipta, rasa, dan karsa manusia yang indah dan dituangkan dalam bentuk bunyi-bunyian, suara melodi, ritme dan harmoni yang dapat membangkitkan emosi, dan bisa membuat mood menjadi bahagia, menghilangkan stress, pengiring selama proses pembelajaran dan bisa untuk mengurangi nyeri.

Proses berkurangnya kecemasan pada pasien hemodialisa yang disebabkan oleh terapi musik klasik (Beethoven) dimulai dengan rangsangan musik klasik yang didengar oleh pasien yang dapat mengaktivasi jalur-jalur spesifik di dalam beberapa area otak, seperti sistem limbik yang berhubungan dengan perilaku emosional. Dengan mendengarkan musik, sistem limbik ini teraktivasi dan individu tersebut pun menjadi rileks. Saat keadaan rileks inilah tekanan darah menurun. Jadi tidak hanya obat Prozak (antidepresi) saja, yang dapat bekerja di sistem Limbik, namun juga terapi musik. Selain itu pula alunan musik dapat menstimulasi tubuh untuk memproduksi molekul yang disebut nitrik oxide (NO). Molekul ini bekerja pada tonus pembuluh darah sehingga dapat mengurangi tekanan darah. Dengan begitu, maka akan sangat bermanfaat jika musik dapat digunakan untuk penurunan tekanan darah pada pasien hipertensi (Turana, 2011).

\section{KESIMPULAN}

Dari 15 pasien hemodialisa dengan gagal ginjal kronik saat sebelum diberikan terapi musik klasik (Beethoven), terdapat 12 pasien $(80 \%)$ mengalami kecemasan berat sedangkan 3 pasien lainnya (20\%) mengalami kecemasan sedang.

Dari 15 pasien hemodialisa dengan gagal ginjal kronik saat setelah diberikan terapi musik klasik (Beethoven), terdapat 2 pasien $(13,33 \%)$ mengalami kecemasan ringan, 11 pasien $(73,34 \%)$ mengalami kecemasan sedang, dan 2 pasien lainnya (13,33\%) mengalami kecemasan berat.

Berdasarkan hasil uji $t$ dependent, diperoleh $p$-value $=0,000$. Karena $p$-value $=$ $0,000<0,05$ maka dapat disimpulkan bahwa terdapat pengaruh signifikan terapi musik klasik (Beethoven) terhadap tingkat kecemasan pada pasien hemodialisa dengan gagal ganjil kronik di RSUD Dr. M Yunus Bengkulu.

\section{SARAN}

Diharapkan hasil penelitian ini dapat menjadi salah satu pilihan terapi untuk menurunkan tingkat kecemasan pasien hemodialisa.

\section{DAFTAR PUSTAKA}

Ariani, S. 2016. Stop Gagal Ginjal dan Gangguan Ginjal lainnya. Yogyakarta: Sitana Media.

Cipta, I, D. 2016. Hubungan Dukungan Keluarga Dengan Kecemasan Pada Pasien Gagal Ginjal Kronis Di Unit Hemodialisa RS PKU Muhammadiyah Unit II Gamping Sleman Yogyakarta. Publikasi IImiah: Fakultas IImu Kesehatan Universitas Aisyi'ah Yogyakarta.

Ghufron, M, Nur \& Rini R,S. 2011. Teori-teori Psikologi. Yogyakarta: Ar Ruz Media.

Kemenkes RI. 2017. Profil Kesehatan Indonesia Tahun 2016. Jakarta: Kemenkes.

Mahatadinar \& Nisa. 2017. Pengaruh Musik Klasik Terhadap Penurunan Tekanan Darah pada Lansia Penderita Hipertensi. Publikasi IImiah: Fakultas Kedokteran Universitas Lampung. 
Potter \& Perry. 2010. Buku Ajar Fundamental Keperawatan. Jakarta: EGC.

Purwati S. (2018). Analisis Faktor Risiko Penyebab Kejadian Penyakit Gagal Ginjal Kronik (GGK) Di Ruangan Hemodialisis. Jurnal Keperawatan Global

Prihananda L.M, Maliya, dan Kartinah. 2016. Effect Of Classical Musik Therapy On The Anxiety Level Of Hemodialysis Patients At The PKU Muhammadiyah Hospital Of Surakarta. Publikasi IImiah: Fakultas IImu Kesehatan UMS.

Ratnawati. 2011. Tingkat Kecemasan Pasien Derngan Tindakan Hemodialisa di BLUD RSUDr M.MDunda Kabupaten Gorontalo. Jurnal Health \& Sport, Vol. 3, Nomor 2, Agustus 2Afi:285 - 362.

Suharyanto T \& Madjid A. 2009. Asuhan Keperawatan Pada Klien dengan Gangguan Sistem Perkemihan. Jakarta: Trans Info Media.
Simulati S, dkk. (2015). Asuhan Keperawatan Gangguan Sistem Perkemihan. Jakarta: Salemba Medika

Sugiyono, (2018). Metode Penelitian Kuantitatif, Kualitatif, dan R\&D. Bandung:ISBN.

Tangian, A. F., Kandou, L. F. J., Munayang, $H$. 2015. Hubungan lamanya menjalani hemodialisis dengan tingkat kecemasan pada pasangan hidup pasien yang menderita penyakit gagal ginjal kronik di RSUP Prof. Dr. R. D. Kandou Manado. Publikasi IImiah: Fakultas IImu Kesehatan Universitas Sam Ratulangi Manado.

Taruna. 2011. Gangguan Tidur Insomnia. Diakses dari www.mediaholistik.com. pada tanggal 27 Oktober 2018.

Yesi H \& Bayhakki. (2017). Hubungan Lama Menjalani Hemodialisis Dengan IDWG Pada Pasien Hemodialisis. JKP 